the number of staff employed. Under the fisheries section, grants are made towards both 'directed' and 'free' research, as it is recognised that much useful information would be lost if only specified lines of research were encouraged. The Development Fund also makes regular advances towards the construction and improvement of harbours and the acquisition of land for road improvements. The total sum recommended in $1934-35$ was $£ 490,968$, compared with $£ 343,636$ in the preceding year, and the report concludes with a detailed summarised schedule of the expenditure.

\section{New Electrical Devices}

IN A.E.G. Progress for the first quarter of 1936 , which is published by the foreign department of the Allgemeine Elektricitäts Gesellschaft of Berlin, the company gives its annual general review of novel electrical devices which are being increasingly used in Germany. One of these is an automatic sequence indicator and timer. In ceramic, chemical and foodstuffs industries, many machines are employed to stir or knead the various ingredients. It is often necessary that these materials be added to the mixture in a definite sequence of time. The new indicator consists of a case containing a number of transparent plates, suitably engraved for each process and lighted up from behind in a predetermined sequence. The attendant is thus warned at the right moment without being obliged to watch the clock. A warning bell is sometimes added to the plate lights. For all kinds of mixing operations this indicator gives useful results. Another device is a 'fan heater' used in conjunction with an electric fire. A silent running fan mounted behind the heating elements circulates the hot air without producing any noticeable draught. The room is quickly and evenly warmed and the hot air can be directed to any point where rapid heating is desired. It is stated that the occupants of a room with a fan heater feel a comfortable warmth on all sides. A switch worked by the foot operates as follows. In position 1 the fan runs cold, operating as a ventilator and using as much power as a small lamp (20 watts) ; in position 2, warm air is emitted, the heater now taking 1,500 watts; and in position 3, it is switched off.

\section{Mineral Development in Canada}

IN a recent series of broadcast addresses, the Minister of Mines at Ottawa emphasised that Canada's vast new mineral wealth is being derived from a line of mining camps extending for 2,400 miles from northern Quebec to Great Bear Lake. Ten years ago, gold production in this belt came from only two districts, whereas to-day mining developments are in progress in a score of separate localities in a region of the Pre-Cambrian shield which is quite unsuitable for agriculture. Thus a new metallic link has been forged between eastern and western Canada which is awakening a new community of interests. The mining camps look to the west for food supplies and to the east for machinery, chemicals, clothing and other factory products. At present the most important section of the new economic frontier is the area including eastern Manitoba, northern Ontario and northern Quebec. Excluding the famous Porcu. pine, Kirkland Lake and Cobalt centres, the Sudbury nickel-copper district, and the eastern Manitoba gold belt, the oldest of the new mines began production only eight years ago. Now there are twenty-eight new mines, and these have given Canada an additional yearly output of gold and copper worth $£ 7,000,000$, a production value more than the annual gold output of Kirkland Lake. The value of the metals produced from this narrow belt alone now exceeds $£ 20,000,000$, while that from Sudbury adds a further $£ 12,000,000$.

\section{Physics at Harvard}

THE new volume of Contributions from the Physical Laboratories of Harvard University consists of reprints of sixty-five papers which have been issued from the laboratories during the years 1933-34. It forms the first volume of Series 2, and its pages are half an inch higher and wider than those of its predecessors. This increase allows papers from double column periodicals like the Physical Review and the Journal of Chemical Physics to be included without change of form, but papers from the one-column proceedings of the American Academy of Arts and Sciences look insignificant on so large a page. The work represented covers almost every branch of physics-general and atomic physics being the theme of about twenty papers, light and electricity about fifteen each, heat about seven and sound and supersonics three, the classification being approximate only. One paper sketches an interesting course of laboratory work for senior students taking up atomic physics. The subjects which appear most often in the titles are the effects of high pressures on the physical properties of materials, and the line and band spectra of substances.

\section{Carnegie Endowment for International Peace}

THE annual report for 1935 of the Division of Intercourse and Education of the Carnegie Endowment for International Peace issued over the signature of Dr. N. Murray Butler, the director, gives an impressive picture of work being done both in the United States and in Europe to develop an inter. national mind and outlook, and particularly in regard to collective security. An unofficial international conference was arranged at Chatham House, London, on March 5-7, 1935, to consider what steps might be taken to restore confidence by promotion of trade and reduction of unemployment, stabilisation of national monetary systems and better organisation of the family of nations to give security and to strengthen the foundations of international peace. Through the organisation of meetings throughout the United States, lectures by visiting Carnegie professors and others, the distribution of books and pamphlets, the arrangement of 'international mind' alcoves in libraries, the international relations clubs, the League of Nations Association and in other ways, the Division has sought to make known the unanimous recom. mendations of the conference and the principles upon which collective security is based.

(Continued on p. 989.) 